\title{
Adsorption of Lead Ions from Aqueous Solutions Using Gamma Irradiated Minerals
}

\author{
Julián Cruz-Olivares, ${ }^{1}$ Gonzalo Martínez-Barrera, ${ }^{2}$ César Pérez-Alonso, ${ }^{1}$ \\ Carlos Eduardo Barrera-Díaz, ${ }^{1}$ María del Carmen Chaparro-Mercado, ${ }^{3}$ \\ and Fernando Ureña-Núñez ${ }^{4}$ \\ ${ }^{1}$ Facultad de Química, Universidad Autónoma del Estado de México, Paseo Colón Intersección Paseo Tollocan S/N, \\ 50120 Toluca, MEX, Mexico \\ ${ }^{2}$ Laboratorio de Investigación y Desarrollo de Materiales Avanzados (LIDMA), Facultad de Química, \\ Universidad Autónoma del Estado de México, Km. 12 de la Carretera Toluca-Atlacomulco, 50200 San Cayetano, MEX, Mexico \\ ${ }^{3}$ Departamento de Ingeniería y Ciencias Químicas, Universidad Iberoamericana, Prol. Paseo de la Reforma 880, \\ Lomas de Santa Fe, Álvaro Obregón, 01210 Ciudad de México, Mexico \\ ${ }^{4}$ Instituto Nacional de Investigaciones Nucleares, AP 18-1027, Col. Escandón, Delegación Miguel Hidalgo, \\ 11801 Ciudad de México, Mexico
}

Correspondence should be addressed to Julián Cruz-Olivares; jcruzo@uaemex.mx

Received 5 July 2016; Revised 7 September 2016; Accepted 20 October 2016

Academic Editor: Julie J. M. Mesa

Copyright (C) 2016 Julián Cruz-Olivares et al. This is an open access article distributed under the Creative Commons Attribution License, which permits unrestricted use, distribution, and reproduction in any medium, provided the original work is properly cited.

\begin{abstract}
For the first time, an irradiated mineral was used as a novel modified adsorbent for lead removal of aqueous solutions. The effects of gamma radiation doses and temperature on the lead adsorption capacity of an unknown mineral were evaluated. The results show that, in the chemisorption process, the highest adsorption capacity $(9.91 \mathrm{mg} / \mathrm{g})$ and the maximum percentage of lead removal (99.1\%) were reached at $40^{\circ} \mathrm{C}$ when using an irradiated mineral at $150 \mathrm{kGy}$. The improvement on the lead adsorption speed was the most important feature of the irradiated mineral. The experimental results were successfully correlated with the pseudo second-order kinetic model. For all results, the average absolute relative deviations (AARD) were less than $13.20 \%$, and the correlation factor $\left(r^{2}\right)$ was higher than 0.998 . Moreover, the average values of the thermodynamic parameters $\left(\Delta G_{0}=-10612 \mathrm{~J} / \mathrm{mol}\right.$, $\Delta H_{0}=-12360 \mathrm{~J} / \mathrm{mol}$, and $\Delta S_{0}=171 \mathrm{~J} / \mathrm{mol} \mathrm{K}$ ) suggest the feasibility of the proposed process, in terms of the endothermic and irreversible chemisorption results; moreover, ion exchange was evaluated through the EDS results. The X-ray diffraction analysis showed that the unknown irradiated mineral is mainly composed of quartz $\left(\mathrm{SiO}_{2}\right)$, calcite $\left(\mathrm{CaCO}_{3}\right)$, and calcium magnesium silicate $\left(\mathrm{Ca}_{0.15} \mathrm{Mg}_{0.85}\right) \mathrm{Mg}\left(\mathrm{SiO}_{6}\right)$.
\end{abstract}

\section{Introduction}

Despite the strict regulations on environmental issues imposed in many countries $[1,2]$, today, it is still possible to find some heavy metal ions in the wastewater because of industrial processes. However, true environmental damage may occur when such polluted water is unconsciously discharged into natural water flows. Not only aquatic animals and plants but also the human health is at risk [3-5]. Lead is one of the most dangerous metals for the human health, especially for children because their growing bodies can absorb a higher quantity than adults [6-8]. Although lead is prohibited in many products, it is still used in commercial products as automotive batteries, paints, cookware, and some Mexican potter glazes $[9,10]$. At low concentrations of lead ions in the blood, some not dangerous diseases such as anemia, diarrhea, and headaches are observed, but, at a higher concentration $(>10 \mu \mathrm{g} / \mathrm{L})$, the liver, kidney, and neurological and reproductive systems can be severely affected [11, 12].

Many treatments for wastewater polluted with lead ions have been proposed, including an adsorption process which 
does not have high effectiveness, unless the adsorbent material shows certain physicochemical and mechanical properties. In recent years, some physical, chemical, and biological treatments on natural raw minerals have been done in order to modify their structure, thus increasing the adsorption capacity or the selectivity $[13,14]$.

In this tenor, many works have been published; for example, the chemical surface modification of mesoporous silica with a tertiary aminosilane using supercritical carbon dioxide showed that the structural ordering of silica was preserved, but the grafting density increased, and the specific surface area and the average pore diameter decreased in the modified adsorbent material [15]. Specifically, for lead adsorption, a chemically modified adsorbent nanoparticle based on the treated low-value agricultural byproduct rice husk was used and it is reported that a maximum lead adsorption capacity of $93.45 \mathrm{mg} / \mathrm{g}$ was achieved [16]. Even the biological modification for mineral adsorbents has been done; such is the case of the functionalized cells with intracellular $\mathrm{CaCO}_{3}$ mineral scaffolds in order to remove $\mathrm{Pb}$ (II) from the aqueous solution. The biosorption capacity of functionalized cells for $\mathrm{Pb}$ (II) was found to be $116.69 \mathrm{mg} / \mathrm{g}$; compared with the pristine yeast cell, the adsorption capacity of the functionalized cells for metals ions was markedly increased [17].

Thermal treatments to obtain spherical mesoporous silica materials by pseudomorphic transformation of silica fume were used too; this modified adsorbent was employed as an effective adsorbent for removing $\mathrm{Pb}^{2+}$ and its capacity demonstrated great improvement [18].

A novel magnetic composite bioadsorbent, graphene oxide and magnetic chitosan-ionic liquids, for removing $\mathrm{Pb}$ (II) from water was developed. The mixture of ionic liquids and graphene oxide and magnetic chitosan resulted in a material to be applied in the adsorption of metal ions. The addition of ionic liquids can not only improve the dispersion of the adsorbent, but also increase the adsorption sites [19].

There is a reported study where gamma radiation was utilized to synthesize a modified adsorbent of chitosan grafted with acrylic acid. Grafting degree was evaluated as a function of a radiation dose, and the removal of $\mathrm{Pb}$ and $\mathrm{Cd}$ ions from aqueous solutions was investigated with both ungrafted and grafted chitosan adsorbents [20]. Gamma radiation was also used as a technique for inducing polymerization in the synthesis of some materials utilized in the removal of heavy metals from wastewater $[13,21]$.

Gamma radiation is a current tool that is used as a decontamination or sterilization process, as well as for modification of the physicochemical properties of materials. In this work, gamma radiation is used for the modification of physicochemical properties of a natural mineral and for improving its adsorption capacity for removing lead ions from industrial wastewater. The main novel aspects in the present work are the validation of the mechanism of the kinetic adsorption process and application of gamma irradiation as a technique to improve the lead adsorption capacity of a mineral.

\section{Materials and Methods}

2.1. Mineral. The natural mineral (from mines located in Oaxaca, Mexico) was provided by Lumogral S.A. de C.V.
Enterprise (Iztapalapa, Mexico City), which has a particle size of $0.149 \mathrm{~mm}$ on average (100 Tyler mesh size).

2.2. Lead Adsorption Experiments. Aqueous solutions with $100 \mathrm{mg} / \mathrm{L}$ lead concentration were prepared by dissolving dried salt $(159.8 \mathrm{mg})$ of lead nitrate $\left[\mathrm{Pb}\left(\mathrm{NO}_{3}\right)_{2}\right]$ in distilled water $(1 \mathrm{~L})$. Then, in $100 \mathrm{~mL}$ of such solution, $1.0 \mathrm{~g}$ of nonirradiated or irradiated mineral was added. These heterogeneous mixtures were heated at constant temperature $(20,30$, and $40^{\circ} \mathrm{C}$ ) and stirred with a shaker at $200 \mathrm{rpm}$ (Lab-Line Incubator-Shaker, USA). Finally, separation of solid adsorbents was obtained by a filtration process, at different contact times $(1,15,30,60,120,180,240$, and $300 \mathrm{~min})$.

2.3. Gamma Irradiation Treatment. The mineral was exposed at different gamma radiation doses using a ${ }^{60} \mathrm{Co}$ source. In this case, the mineral was placed into glass flasks and the applied doses were 10, 50, 100, and $150 \mathrm{kGy}$ at the dose rate of $3.5 \mathrm{kGy} / \mathrm{h}$. The experiments were performed in air at room temperature by using a Transelektro irradiator LGI-01 manufactured by IZOTOP Institute of Isotopes Co. Ltd., Budapest, Hungary, and located at the National Institute of Nuclear Research (ININ, Mexico).

2.4. Characterization of the Absorbent Material. The adsorbent material was dried and its morphological surface was characterized by using a scanning electron microscope (JEOL model JSM-6510LV) coupled with an energy dispersive X-ray probe (EDAX) for semiquantitative elemental analysis. The metal concentrations in the liquid solutions were analyzed by using Atomic Absorption Spectrophotometer (Perkin-Elmer model AA300), according to the standard method for lead detection [22].

Mineral samples were also characterized by X-ray diffraction (XRD), before and after irradiation. The analyses were carried out in a Siemens D5000 diffractometer with $\mathrm{Cu} \mathrm{K} \alpha$ radiation. Data were collected in the radiation angle range from $2 \theta$ of $5^{\circ}$ to $2 \theta$ of $75^{\circ}$.

\section{Results and Discussion}

Chemical composition of nonirradiated and irradiated minerals is shown in Table 1. As in many natural minerals, the most abundant component is oxygen followed by silicon and calcium. The received energy by the mineral after irradiation only modified its ratio of each chemical element. For instance, in the irradiated mineral at $10 \mathrm{kGy}$, concentrations of four of the seven chemical components decreased, when compared with nonirradiated mineral. To compensate it, the concentration of the others increased in the same ratio, such that the final concentration is always $100 \%$. Therefore, each chemical element shows slight variation in the weight percentage after the irradiation process. As it is known, interactions of gamma irradiation with matter may cause different effects; one of them is breaking of chemical bonds, which may be combined and allow the formation of other chemical species. Another effect is the cross-linking of chemical bonds that cause changes in the morphology of matter [21,23]. 
TABLE 1: EDS analysis of nonirradiated and irradiated minerals.

\begin{tabular}{lccccc}
\hline \multirow{2}{*}{ Element } & \multicolumn{5}{c}{ Weight (\%) } \\
& Nonirradiated & $10 \mathrm{kGy}$ & $50 \mathrm{kGy}$ & $100 \mathrm{kGy}$ & $150 \mathrm{kGy}$ \\
\hline $\mathrm{O}$ & 58.22 & 54.05 & 59.59 & 52.10 & 53.07 \\
$\mathrm{Mg}$ & 2.16 & 1.09 & 0.88 & 0.87 & 0.86 \\
$\mathrm{Al}$ & 2.22 & 2.90 & 2.63 & 2.13 & 2.17 \\
$\mathrm{Si}$ & 18.93 & 24.02 & 19.67 & 14.45 & 10.63 \\
$\mathrm{~K}$ & 1.53 & 1.44 & 1.71 & 1.03 & 1.24 \\
$\mathrm{Ca}$ & 13.75 & 14.79 & 14.52 & 28.55 & 31.38 \\
$\mathrm{Fe}$ & 3.19 & 1.71 & 1.00 & 0.87 & 0.65 \\
Total & 100 & 100 & 100 & 100 & 100 \\
\hline
\end{tabular}

TABLE 2: Diffraction peaks of each compound.

\begin{tabular}{lccccccc}
\hline Compound & \multicolumn{7}{c}{ Diffraction peak $(2 \theta)$} \\
\hline Quartz & 21.0 & 26.8 & 50.1 & & & & \\
Calcite $\bullet$ & 23.1 & 29.5 & 36.2 & 39.4 & 43.3 & 47.5 & 48.6 \\
$\begin{array}{l}\text { Calcium } \\
\text { magnesium } \\
\text { silicate } \boldsymbol{\nabla}\end{array}$ & 26.8 & 27.9 & 30.9 & 35.0 & 42.3 & & \\
\hline
\end{tabular}

According to the literature, $\mathrm{Si} / \mathrm{Al}$ ratio is an important parameter in such minerals $[24,25]$. In this case, as it can be seen in the results of Table 1, for nonirradiated mineral, a value of 8.5 is obtained, with the lowest value of 4.9 for irradiated material at $150 \mathrm{kGy}$. Diminution of the $\mathrm{Si} / \mathrm{Al}$ ratio is due to gamma irradiation; this result provides guidelines for future research as acid catalyst. It is observed that as the $\mathrm{Si} / \mathrm{Al}$ ratio decreases, acidity increases [26, 27].

Chemical elements are part of three main compounds: quartz, calcite, and calcium magnesium silicate, as it is shown in the diffraction pattern of the nonirradiated and irradiated minerals (Figure 1). Diffraction peaks of each compound are summarized in Table 2. Moreover, calcium magnesium silicate compound gives the mineral interesting features as adsorbent material.

As it can be seen, at doses of 100 and $150 \mathrm{kGy}$, the most stable phase represented by the calcium magnesium silicate is highlighted, and probably at these highest radiation doses the porosity of the material was increased. So, it is inferred that the highest adsorption capacity is due to the highest radiation dose.

In Figure 2, the lead concentration in the aqueous solution versus time is shown. The values of the removal of lead are shown in Table 3. Such values are obtained by mass balance between the initial lead in the solution $\left(C_{0}=100 \mathrm{mg} / \mathrm{L}\right)$ and the lead concentration at any time.

Faster lead adsorption on irradiated mineral was observed with respect to the nonirradiated one. The highest adsorption values were obtained for higher doses ( $150 \mathrm{kGy}$ ) with time less than 60 minutes. Moreover, according to the removal rate and adsorption capacity results, the highest adsorbent properties are developed for irradiated mineral at $150 \mathrm{kGy}$.

As it is observed in Table 3, during the first 15 minutes of contact, the adsorption rate is high, due to the high gradient

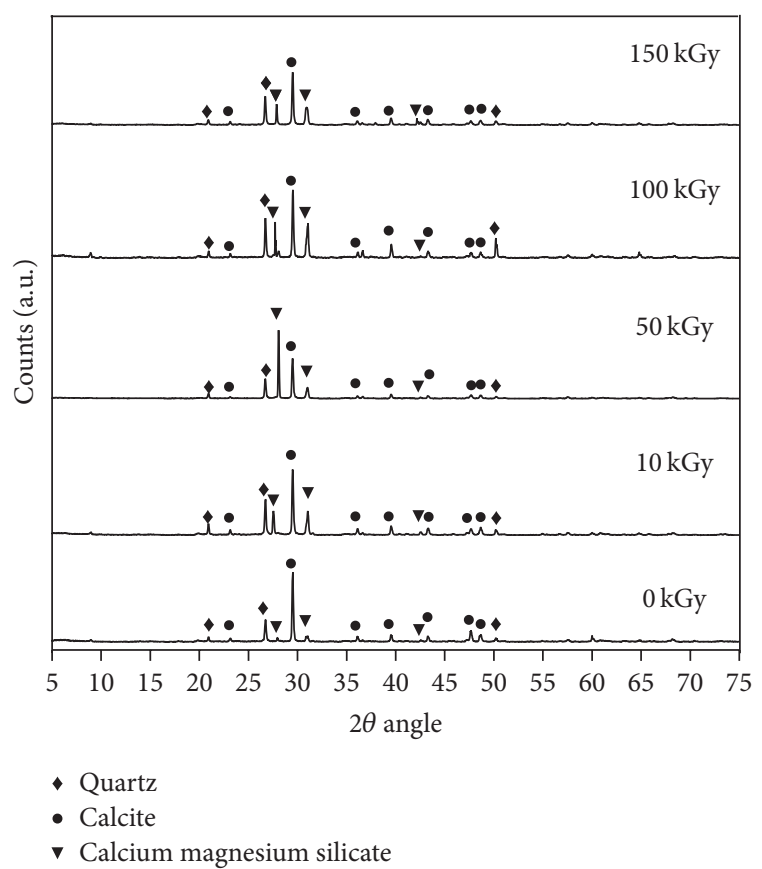

FIGURE 1: X-ray diffraction spectrum of nonirradiated and irradiated minerals.

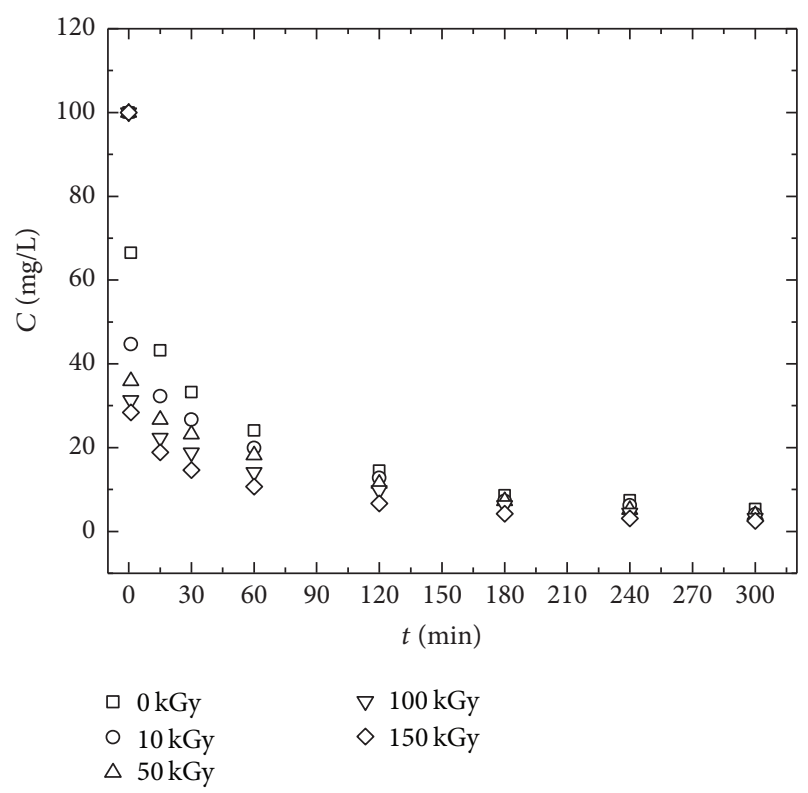

FIGURE 2: Kinetics of the lead adsorption process for nonirradiated and irradiated minerals $\left(C_{0}=100 \mathrm{mg} / \mathrm{L}, T=20^{\circ} \mathrm{C}, w=1 \mathrm{~g}\right.$, and $V=0.1 \mathrm{~L})$.

of the lead concentration between the liquid and the adsorbent surface; this is a common behavior in the mass transfer phenomena as ion exchange and chemisorption processes. Moreover, $80 \%$ of lead is adsorbed for different combinations of contact time and irradiation dose: (a) 30 minutes and $100 \mathrm{kGy}$ or (b) 60 minutes and $10 \mathrm{kGy}$. Thus, diminution of the irradiation dose requires more contact time. At the highest contact time (300 minutes), where the state of equilibrium 
TABLE 3: Lead removal percentage of nonirradiated and irradiated minerals $\left(C_{0}=100 \mathrm{mg} / \mathrm{L}, T=20^{\circ} \mathrm{C}, w=1 \mathrm{~g}\right.$, and $\left.V=0.1 \mathrm{~L}\right)$.

\begin{tabular}{lccccc}
\hline \multirow{2}{*}{$t(\min )$} & \multicolumn{5}{c}{ Lead removal (\%) } \\
& Nonirradiated & $10 \mathrm{kGy}$ & $50 \mathrm{kGy}$ & $100 \mathrm{kGy}$ & $150 \mathrm{kGy}$ \\
\hline 1 & 33.5 & 55.3 & 64.1 & 68.7 & 71.6 \\
15 & 56.8 & 67.7 & 73.3 & 77.7 & 81.1 \\
30 & 66.8 & 73.3 & 76.8 & 81.2 & 85.4 \\
60 & 75.9 & 80.1 & 81.8 & 85.9 & 89.3 \\
120 & 85.5 & 87.2 & 88.6 & 90.2 & 93.3 \\
180 & 91.4 & 92.7 & 92.7 & 93.8 & 95.8 \\
240 & 92.6 & 93.8 & 94.8 & 95.6 & 96.9 \\
300 & 94.7 & 95.9 & 96.1 & 96.8 & 97.5 \\
\hline
\end{tabular}

happens, the adsorption capacity values are almost constant for nonirradiated and irradiated minerals, with only 3\% difference between them. A similar behavior was observed for the other temperatures.

The experimental adsorption capacity was evaluated with the following equation:

$$
q=\frac{\left(C_{0}-C\right) V}{w},
$$

where $q$ is the adsorption capacity $(\mathrm{mg} / \mathrm{g}), C_{0}$ is the initial lead concentration $(\mathrm{mg} / \mathrm{L}), C$ is lead concentration of the filtered solution at any time $(\mathrm{mg} / \mathrm{L}), V$ is sample volume $(\mathrm{L})$, and $w$ is adsorbent mass (g).

As it is known, kinetics of the adsorption process are related to the rate at which the adsorbent material retains a certain quantity of lead. By experimental data of the concentration and contact time, elucidation of the adsorption mechanism was done.

In the case of the adsorption of lead ions on nonirradiated and irradiated minerals, it was assumed that the adsorption rate is proportional to the square of the number of linking atoms. A lead ion $\left[\mathrm{Pb}^{2+}\right]$ present in the aqueous solution would be interacting with 2 oxygen atoms [-O-] in the chemical structure of the mineral surface [28]. Similar results have been found in other systems $[3,4]$.

According to the chemical equation

$$
\left[\mathrm{Pb}^{2+}\right]+2\left[\mathrm{O}^{2-}\right] \longrightarrow[\mathrm{O}-\mathrm{Pb}-\mathrm{O}]^{\neq}
$$

the kinetic equation is

$$
\frac{d q}{d t}=k\left[\mathrm{~Pb}^{2+}\right]\left[\mathrm{O}^{2-}\right]^{2}
$$

where

$$
\begin{gathered}
k\left[\mathrm{~Pb}^{2+}\right]=k_{2} \\
{\left[\mathrm{O}^{2-}\right]=\left(q_{e}-q\right)^{2} .}
\end{gathered}
$$

Then, the kinetic equation can be written as

$$
\frac{d q}{d t}=k_{2}\left(q_{e}-q\right)^{2}
$$

where $q$ is the adsorption capacity $(\mathrm{mg} / \mathrm{g}), q_{e}$ is the adsorption capacity at equilibrium $(\mathrm{mg} / \mathrm{g})$, and $k_{2}$ is the kinetic constant of the pseudo second order.

The differential equation is written in an integrated form:

$$
\frac{t}{q}=\frac{1}{q_{e}} t+\frac{1}{k_{2} q_{e}^{2}}
$$

The experimental results of the adsorption capacity were adjusted with (6), in order to obtain $q_{e}$ and $k_{2}$ parameters; later, the calculated adsorption capacity was estimated and the results are shown in Tables 4 and 5. The comparison between experimental and calculated adsorption capacities was made considering the average absolute relative deviations (AARD), which were determined by

$$
\mathrm{AARD}=\frac{1}{n} \sum \frac{\left|q^{\mathrm{cal}}-q^{\exp }\right|}{q^{\exp }},
$$

where $n$ is the number of data, $q^{\exp }$ is the experimental adsorption capacity obtained with (1), and $q^{\text {cal }}$ is the calculated adsorption capacity through (6).

According to the AARD and $r^{2}$ results shown in Tables 4 and 5 , the pseudo second-order kinetic model represents satisfactorily the adsorption capacity process of lead ions on nonirradiated and irradiated mineral, regardless of the irradiation dose or temperature. The AARD values were lower than $14 \%$, and $r^{2}$ was higher than 0.998 .

Determination of the main thermodynamic parameters of the adsorption process allows knowing the feasibility of the separation process as well as deciding whether it is controlled by physisorption or chemisorption. Such parameters include free energy $\left(\Delta G_{0}\right)$, enthalpy $\left(\Delta H_{0}\right)$, and entropy $\left(\Delta S_{0}\right)$, which are evaluated by using the equilibrium constant $\left(K_{\text {eq }}\right)$ value, as follows:

$$
K_{\text {eq }}=\frac{C_{\text {ads }}}{C_{t}},
$$

where $C_{\text {ads }}$ is the concentration of adsorbed lead by the mineral and $C_{t}$ is the concentration of lead in the supernatant solution.

The relation between $K_{\mathrm{eq}}$ and the free energy is given by

$$
\Delta G_{0}=-R T \ln K_{\mathrm{eq}},
$$

where $T(\mathrm{~K})$ is the absolute temperature and $R$ is the universal gas constant. by

The dependence of $K_{\mathrm{eq}}$ on the temperature is expressed

$$
\ln K_{\text {eq }}=\frac{\Delta H_{0}}{R}\left(\frac{1}{T}\right)+\frac{\Delta S_{0}}{R} .
$$

Since (10) represents a straight line, plotting $\ln K_{\mathrm{eq}}$ versus $(1 / T)$, it is possible to obtain both $\Delta H_{0}$ and $\Delta S_{0}$ from the slope and intercept, respectively.

Although the adsorption process is a natural phenomenon, in order to get the highest adsorption capacity, it is necessary to work at higher temperatures. In this case, 
TABLE 4: Experimental and calculated lead adsorption capacity of nonirradiated and irradiated minerals $\left(C_{0}=100 \mathrm{mg} / \mathrm{L}, T=20^{\circ} \mathrm{C}, w=1 \mathrm{~g}\right.$, and $V=0.1 \mathrm{~L}$ ).

\begin{tabular}{|c|c|c|c|c|c|c|c|c|c|c|}
\hline \multirow{3}{*}{$t(\min )$} & \multicolumn{10}{|c|}{ Adsorption capacity (mg/g) } \\
\hline & \multicolumn{2}{|c|}{ Nonirradiated } & \multicolumn{2}{|c|}{$10 \mathrm{kGy}$} & \multicolumn{2}{|c|}{50 kGy } & \multicolumn{2}{|c|}{$100 \mathrm{kGy}$} & \multicolumn{2}{|c|}{150 kGy } \\
\hline & Exp. & Cal. & Exp. & Cal. & Exp. & Cal. & Exp. & Cal. & Exp. & Cal. \\
\hline 1 & 3.35 & 0.80 & 5.53 & 1.06 & 6.41 & 1.24 & 6.87 & 1.55 & 7.16 & 2.03 \\
\hline 15 & 5.68 & 5.56 & 6.77 & 6.29 & 7.33 & 6.68 & 7.77 & 7.21 & 8.11 & 7.82 \\
\hline 30 & 6.68 & 7.07 & 7.33 & 7.64 & 7.68 & 7.92 & 8.12 & 8.29 & 8.54 & 8.71 \\
\hline 60 & 7.59 & 8.18 & 8.01 & 8.56 & 8.18 & 8.73 & 8.59 & 8.97 & 8.93 & 9.23 \\
\hline 120 & 8.55 & 8.88 & 8.72 & 9.10 & 8.86 & 9.20 & 9.02 & 9.34 & 9.33 & 9.52 \\
\hline 180 & 9.14 & 9.14 & 9.27 & 9.30 & 9.27 & 9.36 & 9.38 & 9.48 & 9.58 & 9.62 \\
\hline 240 & 9.26 & 9.28 & 9.38 & 9.40 & 9.48 & 9.45 & 9.56 & 9.55 & 9.69 & 9.67 \\
\hline 300 & 9.47 & 9.36 & 9.59 & 9.46 & 9.61 & 9.50 & 9.68 & 9.59 & 9.75 & 9.70 \\
\hline AARD (\%) & \multicolumn{2}{|c|}{12.15} & \multicolumn{2}{|c|}{13.13} & \multicolumn{2}{|c|}{13.19} & \multicolumn{2}{|c|}{12.11} & \multicolumn{2}{|c|}{10.46} \\
\hline$r^{2}$ & \multicolumn{2}{|c|}{0.9981} & \multicolumn{2}{|c|}{0.9985} & \multicolumn{2}{|c|}{0.9988} & \multicolumn{2}{|c|}{0.9992} & \multicolumn{2}{|c|}{0.9997} \\
\hline
\end{tabular}

TABLE 5: Experimental and calculated lead adsorption capacity of irradiated mineral at different temperatures $\left(150 \mathrm{kGy}, C_{0}=\right.$ $100 \mathrm{mg} / \mathrm{L}, w=1 \mathrm{~g}$, and $V=0.1 \mathrm{~L}$ ).

\begin{tabular}{|c|c|c|c|c|c|c|}
\hline \multirow{3}{*}{$t(\min )$} & \multicolumn{6}{|c|}{ Adsorption capacity (mg/g) } \\
\hline & \multicolumn{2}{|c|}{$20^{\circ} \mathrm{C}$} & \multicolumn{2}{|c|}{$30^{\circ} \mathrm{C}$} & \multicolumn{2}{|c|}{$40^{\circ} \mathrm{C}$} \\
\hline & Exp. & Cal. & Exp. & Cal. & Exp. & Cal. \\
\hline 1 & 7.16 & 2.03 & 7.46 & 2.27 & 7.73 & 2.81 \\
\hline 15 & 8.11 & 7.82 & 8.39 & 8.09 & 8.67 & 8.51 \\
\hline 30 & 8.54 & 8.71 & 8.74 & 8.9 & 9.04 & 9.17 \\
\hline 60 & 8.93 & 9.23 & 9.15 & 9.38 & 9.37 & 9.55 \\
\hline 120 & 9.33 & 9.52 & 9.47 & 9.63 & 9.66 & 9.74 \\
\hline 180 & 9.58 & 9.62 & 9.63 & 9.72 & 9.74 & 9.81 \\
\hline 240 & 9.69 & 9.67 & 9.78 & 9.76 & 9.86 & 9.85 \\
\hline 300 & 9.75 & 9.7 & 9.85 & 9.79 & 9.91 & 9.87 \\
\hline AARD (\%) & \multicolumn{2}{|c|}{10.46} & \multicolumn{2}{|c|}{10.11} & \multicolumn{2}{|c|}{8.89} \\
\hline$r^{2}$ & \multicolumn{2}{|c|}{0.9997} & \multicolumn{2}{|c|}{0.9997} & \multicolumn{2}{|c|}{0.9989} \\
\hline
\end{tabular}

TABLE 6: Thermodynamic parameters of the lead adsorption process $\left(150 \mathrm{kGy}, C_{0}=100 \mathrm{mg} / \mathrm{L}, w=1 \mathrm{~g}\right.$, and $\left.V=0.1 \mathrm{~L}\right)$.

\begin{tabular}{lcccc}
\hline & $\Delta G_{0}(\mathrm{~J} / \mathrm{mol})$ & $\Delta H_{0}(\mathrm{~J} / \mathrm{mol})$ & $\Delta S_{0}(\mathrm{~J} / \mathrm{mol} \mathrm{K})$ \\
\hline $20^{\circ} \mathrm{C}$ & $30^{\circ} \mathrm{C}$ & $40^{\circ} \mathrm{C}$ & 41326.4 & 171.3 \\
-8929.0 & -10546.8 & -12359.8 & & \\
\hline
\end{tabular}

the higher the temperature, the greater the spontaneity, as an endothermic process (Table 6). Furthermore, a higher value of $\Delta H_{0}$ suggests a chemisorption mechanism for the process. According to the results, it is possible to establish a set of process variables and the conditions to scale up the process to an industrial wastewater treatment plant.

According to the EDS results, a great capacity to adsorb lead ions is observed in Table 1. The ion interchange is present; the $\mathrm{Mg}$ and $\mathrm{Fe}$ ions were substituted by $\mathrm{Pb}$ ions as it is shown in Table 7 by comparing with the results shown in Table 1.

Morphological changes are observed in nonirradiated and irradiated minerals after the lead adsorption process, as it is shown in Figure 3. At higher radiation doses $(50,100$,
TABLE 7: EDS analysis of nonirradiated and irradiated minerals after the lead adsorption process.

\begin{tabular}{lcc}
\hline Element & \multicolumn{2}{c}{ Weight (\%) } \\
\hline $\mathrm{O}$ & Nonirradiated & $150 \mathrm{kGy}$ \\
$\mathrm{Si}$ & 65.56 & 63.29 \\
$\mathrm{Al}$ & 25.13 & 25.72 \\
$\mathrm{~Pb}$ & 4.38 & 4.64 \\
$\mathrm{Ca}$ & 2.29 & 3.15 \\
$\mathrm{~K}$ & 1.38 & 1.57 \\
\hline
\end{tabular}

and $150 \mathrm{kGy}$ ), the porosity of this material increased because the size of the particle decreased drastically; this is most evident at $150 \mathrm{kGy}$ which corresponds to the XRD results. On the other hand, as mentioned earlier, one of the effects of gamma irradiation is the cross-linking of chemical bonds, which produces morphological changes, with an increment on the porosity between them.

\section{Conclusions}

A novel natural mineral adsorbent was obtained, through its structural modification by gamma radiation, in order to increase the adsorption capacity and the percentage of removal of lead from aqueous solutions. The ionizing energy submitted by gamma rays on the mineral allows a high crystallinity degree as well as high chemical stability. The effects of gamma radiation doses and the temperature on the lead adsorption capacity of the mineral were evaluated. The highest adsorption capacity $(9.91 \mathrm{mg} / \mathrm{g})$ and the maximum percentage of lead removal (99.1\%) were reached at $150 \mathrm{kGy}$ and $40^{\circ} \mathrm{C}$, for industrial wastewater with a content of lead of $100 \mathrm{mg} / \mathrm{L}$. The improvement on the lead adsorption speed was the most important feature of the irradiated mineral. The experimental results were successfully correlated with the pseudo second-order kinetic model. In all cases, the average absolute relative deviations (AARD) were lower than $13.20 \%$, and the correlation factor $\left(r^{2}\right)$ was higher than 0.998 . 

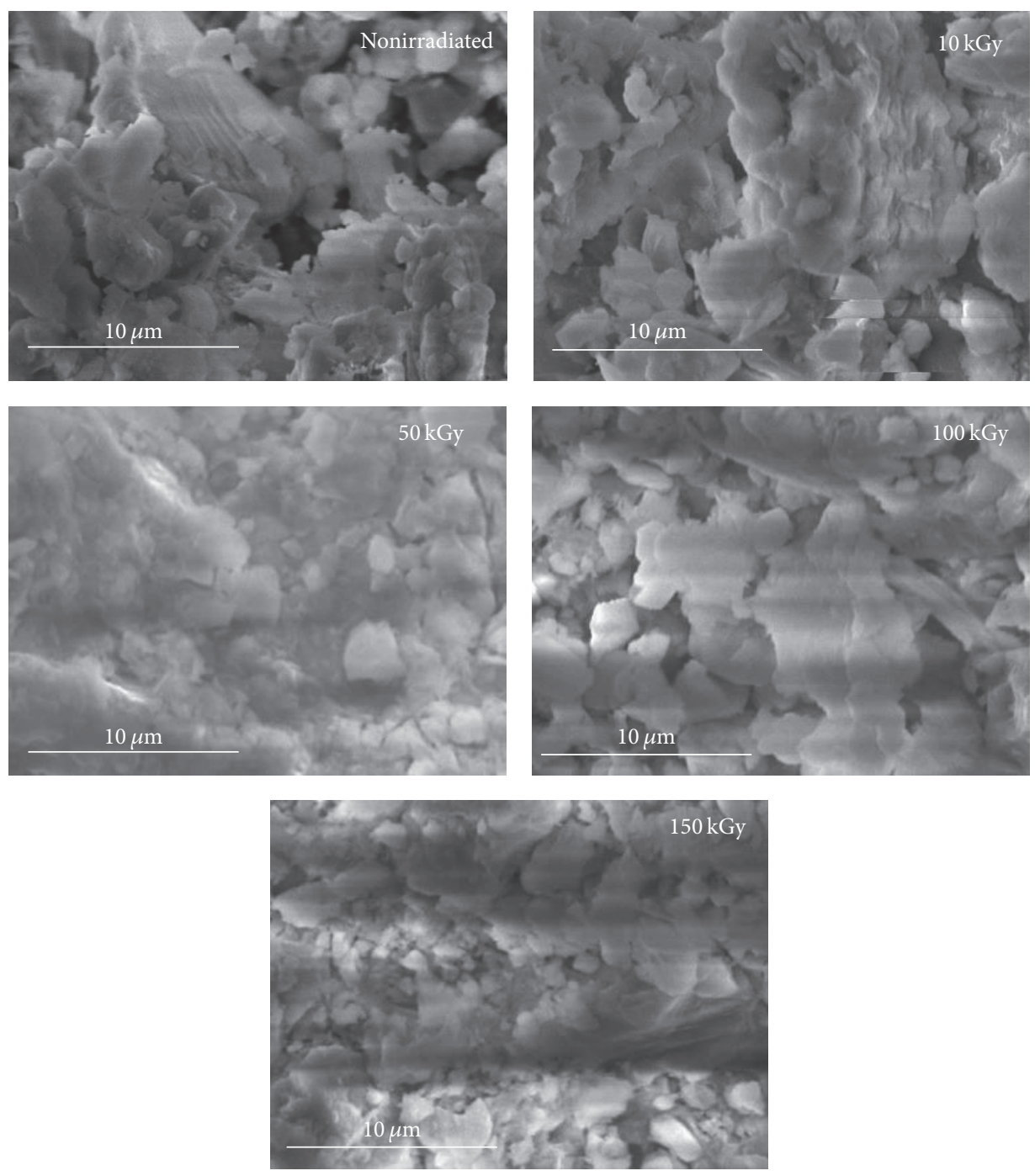

FIGURE 3: SEM images of nonirradiated and irradiated minerals.

Moreover, the thermodynamic parameters values $\left(\Delta G_{0}, \Delta H_{0}\right.$, and $\Delta S_{0}$ ) revealed a feasible, endothermic, and irreversible process, where lead ions are mainly chemisorbed or ionexchanged. The mineral showed specific characteristics: (a) its adsorption capacity is not too high compared with the bioadsorbents, (b) it was insoluble in water, and (c) it had high mechanical strength; thus, the proposed adsorbent can be regenerated and reused, mainly in large-scale processes such as adsorption columns, where large pressure drops are present.

\section{Additional Points}

Highlights. More than 95\% of lead ions contained in industrial wastewater were removed by using an irradiated mineral. The lead adsorption kinetic process was successfully correlated with the pseudo second-order model. The lead adsorption is a spontaneous and endothermic process that achieved higher adsorption capacity at $40^{\circ} \mathrm{C}$. The highest values for lead adsorption capacity were obtained for irradiated mineral at $150 \mathrm{kGy}$, which were $17.5 \%$ higher than that obtained by the nonirradiated one.

\section{Competing Interests}

The authors declare that they have no competing interests.

\section{References}

[1] E. Cordero Arroyo, F. Arroyo Vieyra, R. A. Diaz Lizama, E. Peña Nieto, and M. A. Osorio Chong, "Ley Federal de Responsabilidad Ambiental," Diario Oficial de la Federación. México, vol. 7, article 6, 2013.

[2] M. Greenstone and R. Hanna, "Environmental regulations, air and water pollution, and infant mortality in India," American Economic Review, vol. 104, no. 10, pp. 3038-3072, 2014. 
[3] S. Demim, N. Drouiche, A. Aouabed, and S. Semsari, "CCD study on the ecophysiological effects of heavy metals on Lemna gibba," Ecological Engineering, vol. 57, pp. 302-313, 2013.

[4] S. Demim, N. Drouiche, A. Aouabed, T. Benayad, O. DendeneBadache, and S. Semsari, "Cadmium and nickel: assessment of the physiological effects and heavy metal removal using a response surface approach by L. gibba," Ecological Engineering, vol. 61, pp. 426-435, 2013.

[5] M. Jaishankar, T. Tseten, N. Anbalagan, B. B. Mathew, and K. N. Beeregowda, "Toxicity, mechanism and health effects of some heavy metals," Interdisciplinary Toxicology, vol. 7, no. 2, pp. 6072, 2014.

[6] R. L. Canfield, C. R. Henderson Jr., D. A. Cory-Slechta, C. Cox, T. A. Jusko, and B. P. Lanphear, "Intellectual impairment in children with blood lead concentrations below $10 \mu \mathrm{g}$ per deciliter," The New England Journal of Medicine, vol. 348, no. 16, pp. 1517-1526, 2003.

[7] A. Chen, K. N. Dietrich, J. H. Ware, J. Radcliffe, and W. J. Rogan, "IQ and blood lead from 2 to 7 years of age: are the effects in older children the residual of high blood lead concentrations in 2-year-olds?" Environmental Health Perspectives, vol. 113, no. 5, pp. 597-601, 2005.

[8] S. Wang and J. Zhang, "Blood lead levels in children, China," Environmental Research, vol. 101, no. 3, pp. 412-418, 2006.

[9] J. D. Weidenhamer, P. A. Kobunski, G. Kuepouo, R. W. Corbin, and P. Gottesfeld, "Lead exposure from aluminum cookware in Cameroon," Science of the Total Environment, vol. 496, pp. 339347, 2014.

[10] P. Gottesfeld, "Time to ban lead in industrial paints and coatings," Frontiers in Public Health, vol. 3, no. 144, pp. 1-4, 2015.

[11] L. Charlet, Y. Chapron, P. Faller, R. Kirsch, A. T. Stone, and P. C. Baveye, "Neurodegenerative diseases and exposure to the environmental metals $\mathrm{Mn}, \mathrm{Pb}$, and $\mathrm{Hg}$," Coordination Chemistry Reviews, vol. 256, no. 19-20, pp. 2147-2163, 2012.

[12] N. Arancibia-Miranda, S. E. Baltazar, A. García et al., "Nanoscale zero valent supported by Zeolite and Montmorillonite: template effect of the removal of lead ion from an aqueous solution," Journal of Hazardous Materials, vol. 301, no. 1, pp. 371-380, 2016.

[13] F. Ureña-Nuñez, C. Barrera-Díaz, and B. Bilyeu, "Gamma radiation-polymerized $\mathrm{Zn}$ (II) methacrylate as a sorbent for removal of $\mathrm{Pb}$ (II) ions from wastewater," Industrial and Engineering Chemistry Research, vol. 46, no. 10, pp. 3382-3389, 2007.

[14] S. Kadouche, H. Lounici, K. Benaoumeur, N. Drouiche, M. Hadioui, and P. Sharrock, "Enhancement of sedimentation velocity of heavy metals loaded hydroxyapatite using chitosan extracted from shrimp waste," Journal of Polymers and the Environment, vol. 20, no. 3, pp. 848-857, 2012.

[15] Y. Sánchez-Vicente, C. Pando, M. Cortijo, and A. Cabañas, "Chemical surface modification of mesoporous silica SBA-15 with a tertiary aminosilane using supercritical carbon dioxide," Microporous and Mesoporous Materials, vol. 193, pp. 145-153, 2014.

[16] A. Masoumi, K. Hemmati, and M. Ghaemy, "Low-cost nanoparticles sorbent from modified rice husk and a copolymer for efficient removal of $\mathrm{Pb}(\mathrm{II})$ and crystal violet from water," Chemosphere, vol. 146, no. 2, pp. 253-262, 2016.

[17] X. Ma, W. Cui, L. Yang, Y. Yang, H. Chen, and K. Wang, "Efficient biosorption of lead(II) and cadmium(II) ions from aqueous solutions by functionalized cell with intracellular $\mathrm{CaCO}_{3}$ mineral scaffolds," Bioresource Technology, vol. 185, no. 1, pp. 70-78, 2015.
[18] W. Zhu, X. Li, D. Wu et al., "Synthesis of spherical mesoporous silica materials by pseudomorphic transformation of silica fume and its $\mathrm{Pb} 2+$ removal properties," Microporous and Mesoporous Materials, vol. 222, no. 1, pp. 192-201, 2016.

[19] W. Sun, L. Li, Ch. Luo, and L. Fan, "Synthesis of magnetic graphene nanocomposites decorated with ionic liquids for fast lead ion removal," International Journal of Biological Macromolecules, vol. 85, no. 1, pp. 246-251, 2016.

[20] S. Benamer, M. Mahlous, D. Tahtat et al., "Radiation synthesis of chitosan beads grafted with acrylic acid for metal ions sorption," Radiation Physics and Chemistry, vol. 80, no. 12, pp. 1391-1397, 2011.

[21] F. Ureña-Nuñez, P. Díaz-Jiménez, C. Barrera-Díaz, M. RomeroRomo, and M. Palomar-Pardavé, "Gamma radiation-induced polymerization of $\mathrm{Fe}(\mathrm{II})$ and $\mathrm{Fe}(\mathrm{III})$ methacrylates for $\mathrm{Cr}(\mathrm{VI})$ removal from wastewater," Radiation Physics and Chemistry, vol. 68, no. 5, pp. 819-825, 2003.

[22] APHA, A.W.W.A. Standard Methods for the Examination of Water and Wastewater, American Public Health Association, Washington, DC, USA, 19th edition, 1998.

[23] C. Barrera-Díaz, M. Palomar-Pardavé, M. Romero-Romo, and F. Ureña-Nuñez, "Lead removal from wastewater using $\mathrm{Cu}$ (II) polymethacrylate formed by gamma radiation," Journal of Polymer Research, vol. 12, no. 5, pp. 421-428, 2005.

[24] M. A. Elsheikh, N. Matsue, and T. Henrni, "Effect of Si/AI ratio of allophane on competitive adsorption of phosphate and Oxalate," International Journal of Soil Science, vol. 4, no. 1, pp. 1-13, 2009.

[25] S. S. A. Talesh, S. Fatemi, S. J. Hashemi, and M. Ghasemi, "Effect of Si/Al ratio on $\mathrm{CO}_{2}-\mathrm{CH}_{4}$ adsorption and selectivity in synthesized SAPO-34," Separation Science and Technology, vol. 45, no. 9, pp. 1295-1301, 2010.

[26] D. Coster, A. L. Blumenfeld, and J. J. Fripiat, "Lewis acid sites and surface aluminum in aluminas and zeolites: a highresolution NMR study," The Journal of Physical Chemistry, vol. 98, no. 24, pp. 6201-6211, 1994.

[27] J. Huang, Y. Jiang, V. R. R. Marthala, B. Thomas, E. Romanova, and M. Hunger, "Characterization and acidic properties of aluminum-exchanged zeolites X and Y," The Journal of Physical Chemistry C, vol. 112, no. 10, pp. 3811-3818, 2008.

[28] J. Cruz-Olivares, C. Pérez-Alonso, C. E. Barrera-Díaz, R. Natividad, and M. C. Chaparro-Mercado, "Thermodynamical and analytical evidence of lead ions chemisorption onto Pimenta dioica," Chemical Engineering Journal, vol. 166, no. 3, pp. 814821, 2011. 

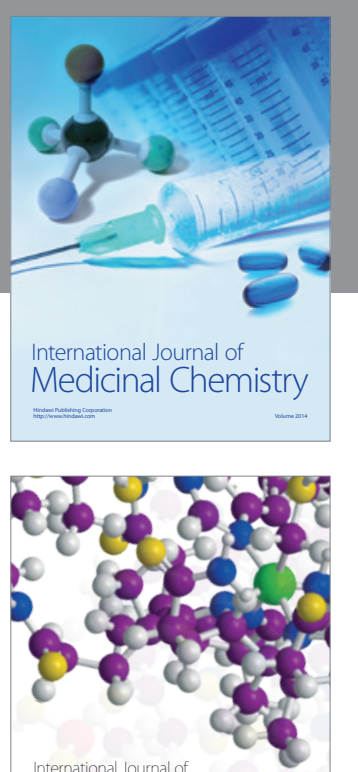

Carbohydrate Chemistry

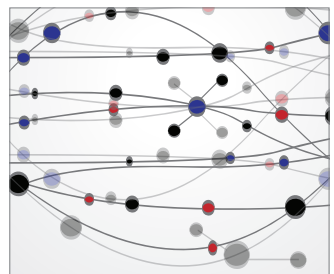

The Scientific World Journal
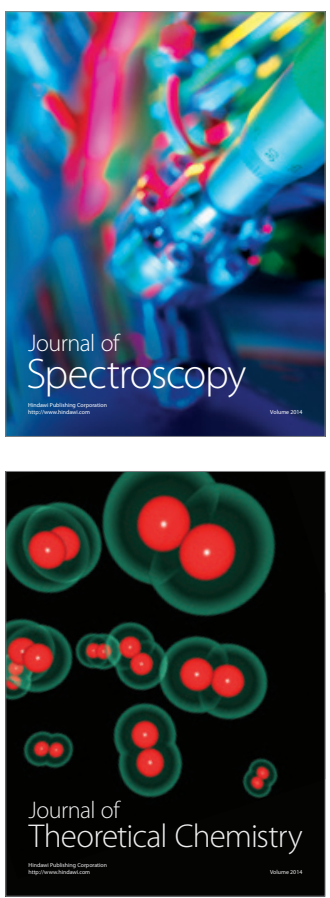
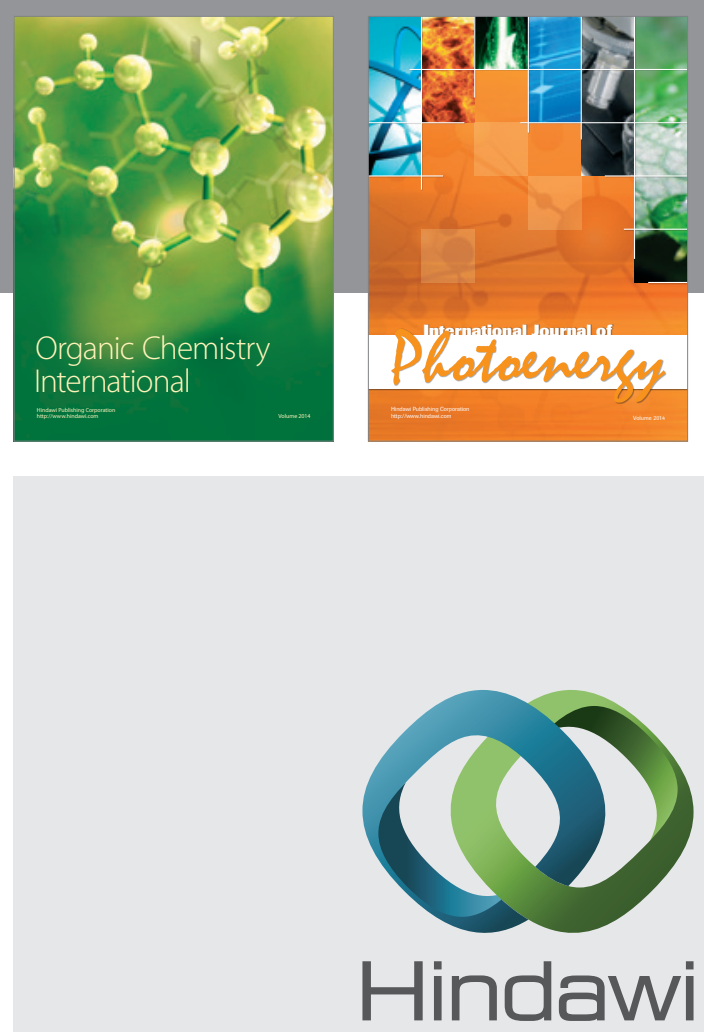

Submit your manuscripts at

http://www.hindawi.com

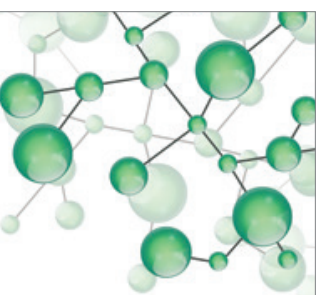

International Journal of

Inorganic Chemistry

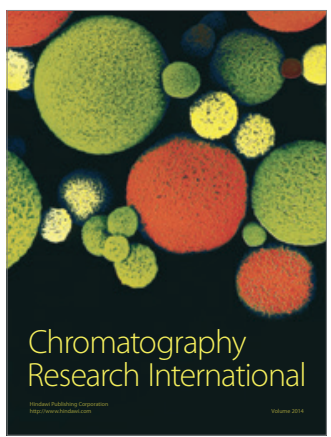

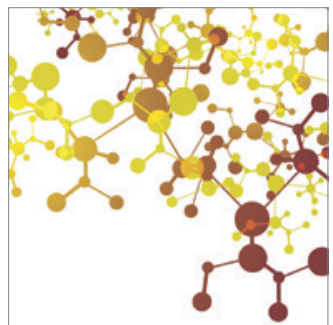

Applied Chemistry
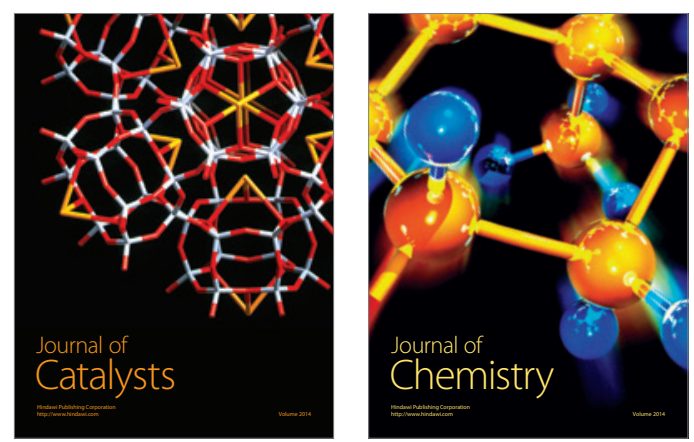
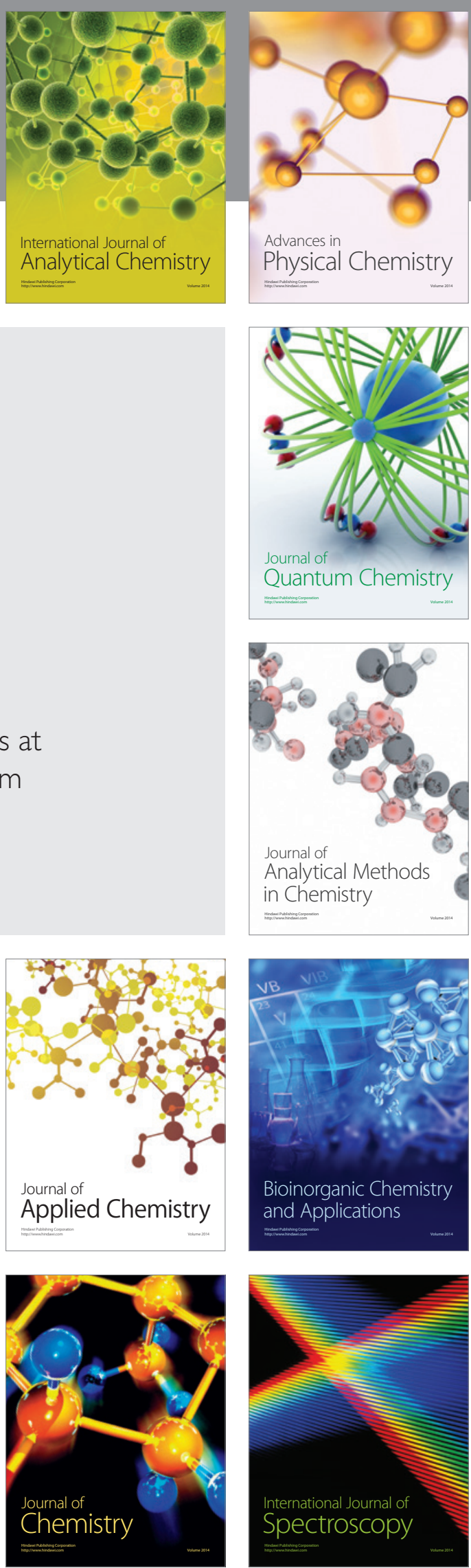